\title{
A METHOD OF CORRELATING GROUNDWATER LEVELS WITH PERCIPITATION
}

DOI: https://doi.org/10.18509/GBP210029d

UDC: 556.313:551.577]:551.501(498)

\author{
Boicu Daniel \\ Minea Ionut \\ Alexandru Ioan Cuza" University of Iasi, Faculty of Geography and Geology, Romania
}

\begin{abstract}
The current climatic context characterized by increasingly extended periods in which the rainfall deficit and high temperatures lead to the need to make forecasts that can identify the increase in the groundwater level from the amount of rainfall. In order to establish forecasts of the groundwater regime, it is necessary to know the complexity and capacity of action of internal and external factors as well as the particularities of the regime. Identifying the correlations that are established between variations in the groundwater level and precipitation, especially where the predominant factor of variation is represented by precipitation, can be a useful tool in establishing forecasts. The possibility of correlations was analyzed at 5 hydrogeological wells located in the northeastern part of Romania for the period 1983-2017, taking into account the monthly data of precipitation and groundwater level variation only for the period of rising levels, that is November - April, May.
\end{abstract}

Keywords: forecast, correlation, groundwater level, hydrogeological wells

\section{INTRODUCTION}

Groundwater is the main reservoir of fresh water and therefore requires special attention when it comes to managing these resources. The most important changes that take place in the variation of the groundwater level are due to the relationship that is established between it and the atmospheric precipitations [1]. Groundwater level studies indicate that precipitation is favorable for underground recharging $[2,3,1,4,5]$ unknown in this relationship being given by the connecting element between surface and underground, the permeability of rocks. The lack of a complex groundwater monitoring system $[6,7]$ as well as the fact that only about $10 \%$ of the rural population is connected to a centralized water supply system [8] leads to critical situations among the water supply of the population especially in years of severe drought $[9,10]$.

Population growth and the anthropogenic impact it brings by intensifying agriculture, industrialization and pollution increase concern about groundwater resources [11]. Climate scenarios highlight the increasingly variable nature of the groundwater level as well as their long-term impact by increasingly limiting groundwater resources $[12,13$, 14]. Starting from the importance of groundwater and the increasingly unpredictable nature of the variation of precipitation in terms of quantity and uneven spatial distribution, it is necessary to make a correlation between atmospheric precipitation and the amplitude of the variation of the groundwater level to predict and have an overview of groundwater resources 


\section{DATASETS AND METHODOLOGY}

\section{Datasets}

The analyzed wells are located in the north-eastern part of Romania, in the territorial administrative unit of Botoșani county (Figure 1). The frequency of the hydrological, pedological and atmospheric drought phenomena that characterize this area leads to a major interest regarding the correlations that are established between the oscillation of groundwater level and the atmospheric precipitation in the area. In the analysis were used the variations of the groundwater level, monthly data, over a period of 34 years (from 1983-2017). In order to be able to perform the forecast analysis and to observe the connection between the precipitations and the groundwater level, the monthly precipitations were also taken into account, for the same period, from the Botoșani meteorological station.

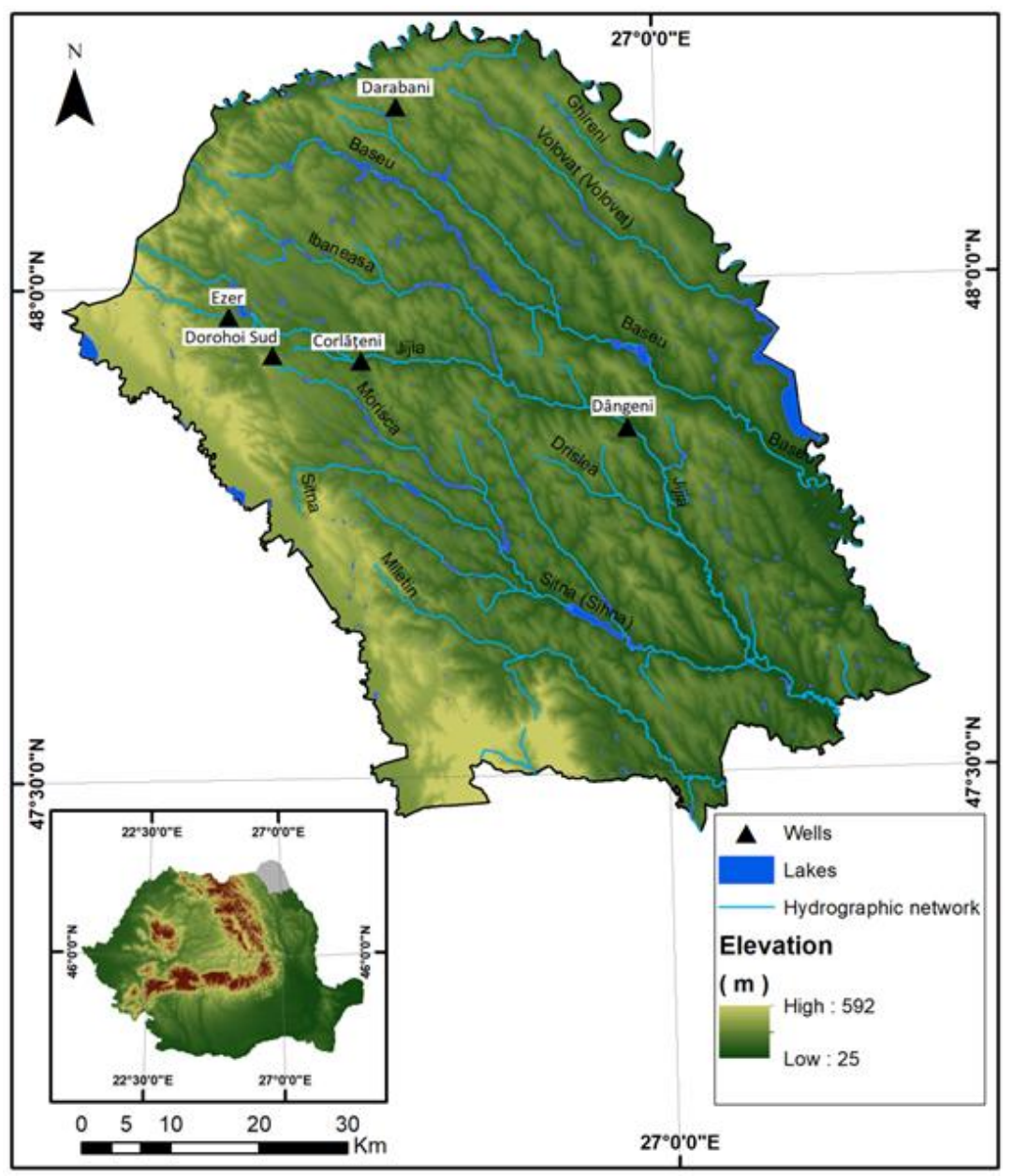

Figure 1. Hydrogeological wells analyzed from study area.

\section{Methodology}

The methodology approached for identifying the correlations that are established between the variation of groundwater levels and precipitation was developed and used by Eleonora Tabacaru Roșescu in 1974 [15]. This methodology is an enriched version of the previous one.

The methodology uses data on the amount of precipitation (monthly) that overlaps over the period of increase in groundwater levels as well as the amplitude of the variation of 
the level in that period. For the analyzed study area, this growth period is from November to April or May. Starting from these data we will obtain a correlation line expressed by a first order equation of type $y=a+b x$. Determining the estimated values of $a$ and $b$ generates a series of characteristics of the correlation line.

Where:

$$
\begin{gathered}
\mathrm{a}=\mathrm{y}-\mathrm{bx} \\
b=\frac{\mathrm{n} * \sum \mathrm{xy}-\sum \mathrm{x} * \sum \mathrm{y}}{n * \sum \mathrm{x}^{2}-\left(\sum \mathrm{x}\right)^{2}}
\end{gathered}
$$

- $=\Delta \mathrm{h}(\mathrm{mm})$ - (for the period November - April, May); $\mathrm{y}=$ sum of precipitation $(\Sigma \mathrm{p})$ in $\mathrm{mm}$, for the same period; $\mathrm{n}=$ number of years taken into account;

- In the correlation between level and precipitation it should be mentioned that:

- $\mathrm{a}=$ lost precipitation (Pp) - that part of precipitation that does not participate in raising groundwater levels, that is that part of the precipitation that is consumed in the processes of saturation of the aeration area and / or by total evaporation;

- $b=$ represents the effective porosity (me) or the rock yield coefficient $(\mu(\%))$. Knowing the value of "b" calculated using expression (2) and the replacement of its unknown in expression (1) we can determine the value of "a" that is the value of lost precipitation $(\mathrm{Pp})$.

From the sum of the fallen precipitations $(\Sigma \mathrm{p})$ we subtract the value corresponding to the lost precipitations $(\mathrm{a}=\mathrm{Pp})$ we obtain the effective precipitations $(\mathrm{Pe})$ that contribute to the raising of the phreatic level. In other words, it represents the contribution of precipitation in the aquifer (3).

$$
\mathrm{Pe}=\mathrm{P}-\mathrm{Pp}
$$

Having the data referring to the lost precipitation and the yield coefficient, we can move on to the calculation of the spring level (forecasted level). Thus, it is necessary to know the amount of precipitation that fell in order to forecast $(\Delta \mathrm{h})$ and increase the respective levels (4).

$$
\Delta \mathrm{h}(\mathrm{mm})=\frac{\mathrm{P}(\mathrm{mm})-\mathrm{Pp}(\mathrm{mm})}{\mu}=\frac{P e}{\mu}
$$

The correlation between the real groundwater level $(\alpha)$ of formula 6 and precipitation was made after the omega $(\Omega)$ of formula 5 was calculated

$$
\begin{gathered}
. \Omega=(\bar{x}-P p) / \mu \\
\alpha=\Delta \mathrm{h}+( \pm \Delta \mathrm{h} * \Omega) / 100
\end{gathered}
$$

\section{RESULTS}

The analysis of the correlation between the variation of the groundwater level and the atmospheric precipitations raises a whole series of unknowns that act on the process of underground water storage. In most of the cases of analysis of these two parameters it was found that a statistically or graphically valid correlation cannot be established [16]. The location of the study area in the area where groundwater is exploited uncontrollably by about $70 \%$ of the rural population is another impasse that adds to the set of unknowns in the study of this field. In an attempt to have a clearer picture, it is necessary to make spring forecasts [17]. 
Table 1. Centralizer with the data necessary for the correlation graph

\begin{tabular}{|c|c|c|c|c|c|c|c|c|c|c|c|c|}
\hline Period & $\begin{array}{c}\Delta \mathbf{h} \\
(\mathbf{m m})\end{array}$ & \begin{tabular}{|c|} 
Precipi \\
tation \\
$(\mathrm{mm})$
\end{tabular} & $\mathbf{x}^{2}$ & $\mathbf{y}^{2}$ & $\mathbf{X y}$ & $\mu(\%)$ & $\begin{array}{c}\mathbf{P p} \\
(\mathbf{m m})\end{array}$ & $\begin{array}{c}\mathbf{P e} \\
(\mathbf{P}-\mathbf{P p})\end{array}$ & $\begin{array}{c}\Delta h \\
\text { forecast } \\
(\mathrm{cm})\end{array}$ & $\begin{array}{l} \pm \Delta \mathrm{h} \\
(\mathrm{cm})\end{array}$ & $\begin{array}{c}\Delta \mathrm{h} \\
(\mathrm{cm})\end{array}$ & $\begin{array}{c}\alpha \\
(\mathbf{c m})\end{array}$ \\
\hline 1983-1984 & 430 & 326.8 & 184900 & 106798.2 & 140524 & 0.25 & 147.1 & 179.8 & 70.9 & 27.9 & 43 & 61.4 \\
\hline 1984-1985 & 320 & 230.1 & 102400 & 52946.01 & 73632 & 25.35 & & 83.1 & 32.8 & 0.8 & 32 & 32.5 \\
\hline 1985-1986 & 380 & 159.8 & 144400 & 25536.04 & 60724 & & & 12.8 & 5.1 & -32.9 & 38 & 16.3 \\
\hline 1986-1987 & 230 & 167 & 52900 & 27889 & 38410 & & & 20.0 & 7.9 & -15.1 & 23 & 13.0 \\
\hline $1987-1988$ & 780 & 367.8 & 608400 & 135276.8 & 286884 & & & 220.8 & 87.1 & 9.1 & 78 & 84.0 \\
\hline 1988-1989 & 120 & 176.3 & 14400 & 31081.69 & 21156 & & & 29.3 & 11.6 & -0.4 & 12 & 11.7 \\
\hline 1989-1990 & 190 & 148.1 & 36100 & 21933.61 & 28139 & & & 1.1 & 0.4 & -18.6 & 19 & 6.7 \\
\hline 1990-1991 & 500 & 309.1 & 250000 & 95542.81 & 154550 & & & \begin{tabular}{|l|}
162.1 \\
\end{tabular} & 64.0 & 14.0 & 50 & 59.2 \\
\hline 1991-1992 & 220 & 165.4 & 48400 & 27357.16 & 36388 & & & 18.4 & 7.3 & -14.7 & 22 & 12.3 \\
\hline 1992-1993 & 580 & 284.8 & 336400 & 81111.04 & 165184 & & & \begin{tabular}{|l|}
137.8 \\
\end{tabular} & 54.4 & -3.6 & 58 & 55.6 \\
\hline 1993-1994 & 190 & 210.9 & 36100 & 44478.81 & 40071 & & & 63.9 & 25.2 & 6.2 & 19 & 23.1 \\
\hline 1994-1995 & 620 & 256.2 & 384400 & 65638.44 & 158844 & & & \begin{tabular}{|l|}
109.2 \\
\end{tabular} & 43.1 & -18.9 & 62 & 49.5 \\
\hline 1995-1996 & 740 & 243.9 & 547600 & 59487.21 & 180486 & & & 96.9 & 38.2 & -35.8 & 74 & 50.4 \\
\hline 1996-1997 & 500 & 279.6 & 250000 & 78176.16 & 139800 & & & \begin{tabular}{|l|}
132.6 \\
\end{tabular} & 52.3 & 2.3 & 50 & 51.5 \\
\hline 1997-1998 & 350 & 330.2 & 122500 & 109032 & 115570 & & & \begin{tabular}{|l|}
183.2 \\
\end{tabular} & 72.3 & 37.3 & 35 & 59.6 \\
\hline 1998-1999 & 260 & 229.4 & 67600 & 52624.36 & 59644 & & & 82.4 & 32.5 & 6.5 & 26 & 30.3 \\
\hline 1999-2000 & 330 & 185.9 & 108900 & 34558.81 & 61347 & & & 38.9 & 15.4 & -17.6 & 33 & 21.4 \\
\hline $2000-2001$ & 260 & 212.6 & 67600 & 45198.76 & 55276 & & & 65.6 & 25.9 & -0.1 & 26 & 25.9 \\
\hline 2001-2002 & 160 & 193.4 & 25600 & 37403.56 & 30944 & & & 46.4 & 18.3 & 2.3 & 16 & 17.5 \\
\hline $2002-2003$ & 150 & 188.5 & 22500 & 35532.25 & 28275 & & & 41.5 & 16.4 & 1.4 & 15 & 15.9 \\
\hline $2003-2004$ & 260 & 137.8 & 67600 & 18988.84 & 35828 & & & -9.2 & -3.6 & -29.6 & 26 & 6.4 \\
\hline $2004-2005$ & 840 & 376.7 & 705600 & 141902.9 & 316428 & & & \begin{tabular}{|l|}
229.7 \\
\end{tabular} & 90.6 & 6.6 & 84 & 88.4 \\
\hline $2005-2006$ & 290 & 295.1 & 84100 & 87084.01 & 85579 & & & \begin{tabular}{|l|}
148.1 \\
\end{tabular} & 58.4 & 29.4 & 29 & 48.4 \\
\hline 2006-2007 & 120 & 168.8 & 14400 & 28493.44 & 20256 & & & 21.8 & 8.6 & -3.4 & 12 & 9.8 \\
\hline $2007-2008$ & 550 & 356.5 & 302500 & 127092.3 & 196075 & & & \begin{tabular}{|l|}
209.5 \\
\end{tabular} & 82.7 & 27.7 & 55 & 73.3 \\
\hline 2008-2009 & 300 & 196.9 & 90000 & 38769.61 & 59070 & & & 49.9 & 19.7 & -10.3 & 30 & 23.2 \\
\hline $2009-2010$ & 410 & 352.3 & 168100 & 124115.3 & 144443 & & & 205.3 & 81.0 & 40.0 & 41 & 67.4 \\
\hline $2010-2011$ & 450 & 176 & 202500 & 30976 & 79200 & & & 29.0 & 11.4 & -33.6 & 45 & 22.9 \\
\hline 2011-2012 & 440 & 229.9 & 193600 & \begin{tabular}{|l|}
52854.01 \\
\end{tabular} & 101156 & & & 82.9 & 32.7 & -11.3 & 44 & 36.5 \\
\hline $2012-2013$ & 640 & 341.1 & 409600 & 116349.2 & 218304 & & & \begin{tabular}{|l|}
194.1 \\
\end{tabular} & 76.6 & 12.6 & 64 & 72.3 \\
\hline 2013-2014 & 270 & 341.3 & 72900 & 116485.7 & 92151 & & & \begin{tabular}{|l|}
194.3 \\
\end{tabular} & 76.7 & 49.7 & 27 & 59.8 \\
\hline $2014-2015$ & 380 & 179.9 & 144400 & 32364.01 & 68362 & & & 32.9 & 13.0 & -25.0 & 38 & 21.5 \\
\hline $2015-2016$ & 370 & 246.1 & 136900 & 60565.21 & 91057 & & & 99.1 & 39.1 & 2.1 & 37 & 38.4 \\
\hline $2016-2017$ & 460 & 251.2 & 211600 & 63101.44 & 115552 & & & \begin{tabular}{|l|}
104.2 \\
\end{tabular} & 41.1 & -4.9 & 46 & 42.8 \\
\hline$\Sigma=34$ & 13090 & \begin{tabular}{|l|}
8315.4 \\
\end{tabular} & 6214900 & 2206745 & 3499309 & & & & & & & \\
\hline \multirow{2}{*}{$\begin{array}{c}\text { Average }= \\
\Omega=\end{array}$} & $\mathrm{x}=385$ & $y=244.5$ & & & & & & & & & & \\
\hline & 66 & & & & & & & & & & & \\
\hline
\end{tabular}

Following the application of the methodology and the analysis of the obtained results, it was found that there are major differences between $\Delta \mathrm{h}$ obtained from the measurements made by the state institutions and $\Delta \mathrm{h}$ obtained by forecast (mathematically calculated). (Table 1). 

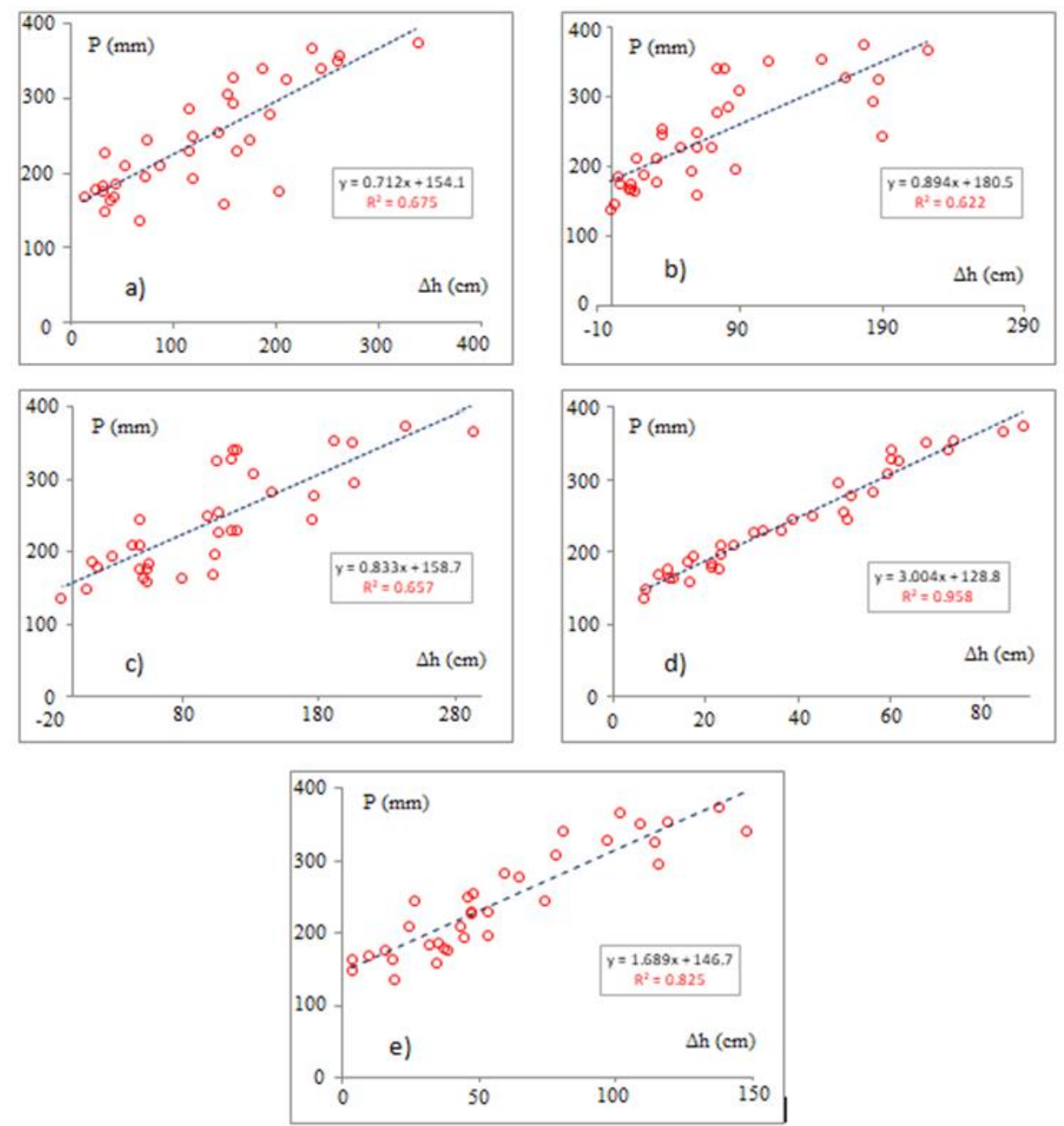

Figure 2. Correlation between precipitation and amplitude of the groundwater level (November 1983 - May 2017) at wells: a) Darabani; b) Dorohoi Sud; c) Ezer; d) Corlățeni; e) Dângeni.

Starting from the fact that the variations of the groundwater level are mainly influenced by the variation of the atmospheric precipitations and the permeability of the rocks, a new index was calculated starting from the difference between the variation of the measured and the calculated groundwater level $( \pm \Delta \mathrm{h})$.

The analysis of the correlation graphs (Figure 2) that were made following the application of the new methodology highlights graphical and statistical correlations that are between the threshold of 0.6 and higher than $0.9[18,19]$. The weakest value of the correlation can be observed in the Dorohoi ud dwell (Figure 2, b), well that is located in an area where variations of the groundwater level are identified that cause an anthropogenic footprint, being an area with a high anthropogenic level, value of 0.622 .

Table 2. Calculated parameters for wells.

\begin{tabular}{lllllll}
\hline Well & Period & $\begin{array}{l}\text { Medium } \\
\text { groundwater } \\
\text { level }(\mathbf{m})\end{array}$ & $\boldsymbol{\mu}(\boldsymbol{\%})$ & $\mathbf{P p}$ & $\boldsymbol{\alpha}(\boldsymbol{\%})$ & Correlation \\
\hline Darabani & $1983-2017$ & $3 \mathrm{~m}-4 \mathrm{~m}$ & 4.1 & 192.3 & 27 & 0.675 \\
Dorohoi Sud & $1983-2017$ & $3 \mathrm{~m}-4 \mathrm{~m}$ & 6.4 & 199.1 & 23 & 0.622 \\
Ezer & $1983-2017$ & $6 \mathrm{~m}-7 \mathrm{~m}$ & 4.9 & 193.6 & 26 & 0.657 \\
Corlățeni & $1983-2017$ & $1 \mathrm{~m}-2 \mathrm{~m}$ & 25.35 & 147.1 & 66 & 0.958 \\
Dângeni & $1983-2017$ & $2 \mathrm{~m}-3 \mathrm{~m}$ & 12.3 & 173.4 & 41 & 0.825 \\
\hline
\end{tabular}


The application of the methodology to the rest of the wells observed highlighted the fact that the strongest correlations are characteristic of those wells whose groundwater level is located closer to the topographic surface and the permeability has higher values. The Corlățeni well with a permeability of $25.35 \%$ and an average value of the groundwater level of $1-2 \mathrm{~m}$ is noticed, followed by the Dângeni well with a permeability of $12.3 \%$ and an average value of the groundwater level of 2-3m (Table 2).

\section{CONCLUSIONS}

The analysis of the correlations that are established between precipitation and the amplitude of the variation of the groundwater level resulting from the determination of spring forecasts can be useful in making plans to reduce negative effects in the underground given that the degree of mutual influence in calculation. The approached methodology is characterized by the simplicity of performing hydrogeological calculations and ease in interpreting the obtained data. It is especially useful in terms of the fact that it can be used in a large data set, it excludes a series of hydrogeological calculations that characterize the filtering properties of rocks (whose determination over time is expensive) generating these data only based on the amplitude of levels and rainfall.

\section{Aknowledgement:}

This work was supported by a grant of the Romanian Ministry of Education and Research CNCS-UEFISCDI, project number PN-III-P1-1.1-TE-2019-0286, within PNCDI III. The authors are grateful for the hydrogeological data provided by the Prut Barlad Basin Branch of the Romanian National Water Administration.

\section{REFERENCES}

[1] Taylor RG, Todd MC, Kongola L, Maurice L, Nahozya E, Sanga H, MacDonald AM, Evidence of the dependence of groundwater resources on extreme rainfall in East Africa, Nat Clim Chang 3:374-378, 2013.

[2] Taylor RG, Howard KWF, The influence of tectonic setting on the hydrological characteristics of deeply weathered terrains: evidence from Uganda, J Hydrol. 218:44-71, 1999.

[3] Owor M, Taylor RG, Tindimugaya C, Mwesigwa D, Rainfall intensity and groundwater recharge: empirical evidence from the upper Nile Basin, Environ Res Lett 4:035009, 2009

[4] Jasechko S, Taylor RG, Intensive rainfall recharges tropical groundwaters. Environ Res Lett, 10:124015, 2015.

[5] Kotchoni, D.O.V., Vouillamoz, JM., Lawson, F.M.A. et al. Relationships between rainfall and groundwater recharge in seasonally humid Benin: a comparative analysis of long-term hydrographs in sedimentary and crystalline aquifers, Hydrogeol J 27, 447-457, 2019.

[6] Minea I, Croitoru A.E., Groundwater response to changes in precipitations in north-eastern Romania, Environmental Engineering and Management Journal, 16, 3, 643-651, 2017.

[7] Boicu D., Minea I., Chelariu O.E., Iosub M., Evaluation on groundwater recharges capacity using AHP method. Case study: the Moldavian Plain, Air and water components of the Environment, 2019

[8] Rotaru A, Raileanu P., Groundwater contamination from waste storage works, Environmental Engineering and Management Journal, 7, 731-735, 2008.

[9] Stângă I.C., Bazinul Tutovei. Riscuri natural și vulnerabilitatea teritoriului, „Al.I.Cuza” University Press, 2012 (in Romanian). 
[10] Sfî̀ca L, Croitoru AE, Iordache I, Ciupertea AF, Synoptic Conditions Generating Heat Waves and Warm Spells in Romania. Athmosfere, 8, 3, 50, 2017.

[11] Vörösmarty, C., McIntyre, P., Gessner, M. et al, Global threats to human water security and river biodiversity, Nature 467, 555-561, 2010.

[12] Hiscock, K., Sparkes, R., Hodgson, A., Evaluation of future climate changes impacts on European groundwater resources in Climate Change Effects of Groundwater Resources: A Global Synthesis of Findings and Recommendations eds. Holger Treidel,Jose Luis Martin-Bordes, Jason J. Gurdak, CRC Press, 2011.

[13] Famiglietti, J.S.,The global groundwater crisis, Nature Climate Change, 4, 945-948, 2014.

[14] Gorelick, S.M., Zheng, C., Global change and the groundwater management challenge, Water Resources Research, 51, 3031-3051. 2015.

[15] Tăbăcaru R. E, Studii de hidrogeologie - Metodica de prelucrare a datelor provenite din rețeaua de observații și măsurători a apelor freatice, București, 1974 (in Romanian).

[16] Minea I., Boicu D., Iosub M., Chelariu O.E., Enea A., Groundwater drought evaluation in north-eastern part of Romania, International Scientific Conference Geobalcanica, 556.313:551.577_38(498), 2020.

[17] Panaitescu V. E, Acviferul freatic și de adâncime din bazinul hidrografic Bârlad, Casa editorială Demiurg, 2008 (in Romanian).

[18] Ratner B, The correlation coefficient: Its values range between $+1 /-1$, or do they?, Journal of Targeting, Measurmeant and analysis for marketing, vol.17.2 139-142, 2009.

[19] Patrichi C., Metode statistice aplicate în climatologie, Terra Nostra, 2009 (in Romanian). 